\title{
Patient safety challenges in primary health care: a scoping review
}

\author{
Desafios da segurança do paciente na atenção primária à saúde: revisão de escopo \\ Desafíos de la seguridad del paciente en atención primaria de salud: revisión exploratoria
}

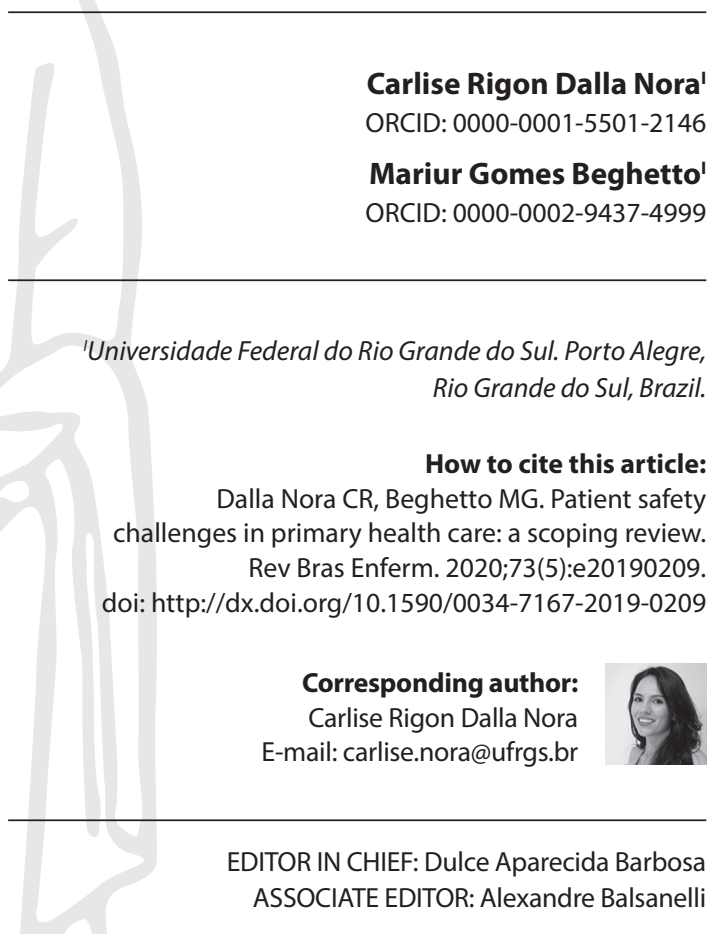

Submission: 06-05-2019

Approval: 12-19-2019

\begin{abstract}
Objectives: to identify the patient safety challenges described by health professionals in Primary Health Care. Methods: a scoping review was conducted on the LILACS, MEDLINE, IBECS, BDENF, and CINAHL databases, and on the Cochrane, SciELO, Pubmed, and Web of Science libraries in January 2019. Original articles on patient safety in the context of Primary Health Care by health professionals were included. Results: the review included 26 studies published between 2002 and 2019. Four categories resulted from the analysis: challenges of health professionals, administration challenges of health services, challenges with the patient and family, and the potential enhancing resources for patient safety. Conclusions: patient safety challenges for Primary Care professionals are multiple and complex. This study provides insight into resources to improve patient safety for health care professionals, patients, administrators, policy makers, educators, and researchers.

Descriptors: Patient Safety; Primary Health Care; Nursing; Patient Care Team; Review.
\end{abstract}

\section{RESUMO}

Objetivos: identificar os desafios da segurança do paciente descritos pelos profissionais de saúde na atenção primária à saúde. Métodos: realizou-se uma revisão de escopo nas bases LILACS, MEDLINE, IBECS, BDENF e CINAHL, e nas bibliotecas Cochrane, SciELO, PubMed e Web of Science em janeiro de 2019. Incluíram-se artigos originais, realizados com profissionais de saúde, sobre a segurança do paciente no contexto da atenção primária à saúde. Resultados: a revisão abrangeu 26 estudos publicados entre 2002 e 2019. Da análise, resultaram quatro categorias: desafios dos profissionais de saúde, desafios da gestão dos serviços de saúde, desafios com o usuário e família e recursos potencializadores da segurança do paciente. Conclusões: os desafios da segurança do paciente para os profissionais da atenção primária são múltiplos e complexos. Este estudo fornece conhecimento sobre recursos para melhorar a segurança do paciente para profissionais de saúde, pacientes, gestores, formuladores de políticas, educadores e pesquisadores.

Descritores: Segurança do Paciente; Atenção Primária à Saúde; Enfermagem; Equipe de Assistência ao Paciente; Revisão.

\section{RESUMEN}

Objetivos: identificar los desafíos de la seguridad del paciente descriptos por profesionales de salud en atención primaria de salud. Métodos: se realizó revisión exploratoria en bases LILACS, MEDLINE, IBECS, BDENF y CINAHL, y en bibliotecas Cochrane, SciELO, PubMed y Web of Science en enero de 2019. Se incluyeron artículos originales, realizados con profesionales de salud sobre seguridad del paciente en ámbito de atención primaria. Resultados: la revisión incluyó 26 estudios publicados entre 2002 y 2019. El análisis determinó cuatro categorías: desafíos de los profesionales de salud; desafíos de la gestión de servicios de salud; desafíos con los usuarios y familia; y recursos potenciadores de la seguridad del paciente. Conclusiones: los desafíos de la seguridad del paciente son, para los profesionales de atención primaria, múltiples y complejos. Este estudio brinda conocimiento sobre recursos para mejorar la seguridad del paciente para profesionales de salud, pacientes, gestores, formuladores de políticas, educadores e investigadores.

Descriptores: Seguridad del Paciente; Atención Primaria de Salud; Enfermería; Grupo de Atención al Paciente; Revisión. 


\section{INTRODUCTION}

Concerns about patient safety are present in health systems worldwide ${ }^{(1)}$. The perception of patient safety in hospitals is well established $^{(2)}$. According to the World Health Organization (WHO) (3), there are few studies related to patient safety in primary health care (PHC). There is a mistaken perception that in $\mathrm{PHC}$ the user is less susceptible to unsafe practices ${ }^{(4)}$. In recent years, patient safety has started to be debated in this context and to take place in systematic reviews ${ }^{(5-7)}$.

A study ${ }^{(8)}$ on the characteristics of adverse events, carried out with $\mathrm{PHC}$ professionals, highlights that the most common events are associated with failures in drug treatment and during the PHC diagnosis phase. Another study ${ }^{(6)}$ suggests that incidents related to diagnosis and prescription are the most likely to result in serious damage. In addition to these, authors ${ }^{(9)}$ report that miscommunication is the most common problem that contributed to the occurrence of errors in PHC.

Although PHC incidents can be less harmful than some that occur in hospitals, they can be of great magnitude, due to the high number of users, services and procedures performed throughout the lives of people at this level of the health care network ${ }^{(10)}$. PHC is considered the coordinator of care and the user's choice to enter different fields in the health care networks (RAS) ${ }^{(11)}$. Despite this, the topic of patient safety in $\mathrm{PHC}$ has not been explored to the same extent as in hospital settings, and is still scarce in the literature ${ }^{(8,10)}$.

A study ${ }^{(1)}$ found that nurses are the professionals who have the most positive scores in relation to the safety culture in $\mathrm{PHC}$ (67.7\%), while dentists have $58.06 \%$ and doctors, $51.79 \%$. In this sense, patient care is not for just one group of health, it runs through all professional categories. Thus, health professionals need to work together, with effective communication, responsibility and competence so that there is safe and quality care ${ }^{(11)}$.

In this context, taking into account the National Primary Care Policy (PNAB) and the National Patient Safety Program, which encourage the implementation of patient safety actions within the $\mathrm{PHC}^{(1)}$, this study aims to identify the challenges pointed in the literature written health professionals, with regard to patient safety in the context of PHC. It is also highlighted the relevance and development of studies related to this theme as a way of enhancing and disseminating the literature in the area, reducing existing knowledge gaps and sensitizing health professionals about the challenges of patient safety also in PHC.

\section{OBJECTIVES}

To identify the patient safety challenges described by health professionals in primary health care.

\section{METHODS}

\section{Ethical aspects}

Ethical aspects and copyright were respected and references were made to the authors of the studies in question. in the case of a bibliographic research, ethical assessment was not necessary.

\section{Study design}

This scoping review was prepared according to the method recommended by the Joanna Briggs Institute Reviewers'Manual ${ }^{(12)}$, according to the theoretical framework proposed by Arksey and O'Malley ${ }^{(13)}$. This type of research consists of an exploratory review ${ }^{(14)}$ designed to map, in scientific production, relevant studies in a given subject.

\section{Methodological procedure}

The steps of the scope review ${ }^{(12)}$ were followed: identification of the research question; inclusion criteria; research strategy; extraction of results; and presentation of results. The sixth step of the consultation, considered optional, was not used ${ }^{(13)}$.

\section{Identification of the research question}

The research question of this study was elaborated according to the mnemonic combination PCC ${ }^{(13)}$ (P: Population - health professionals; C: Concept - Patient safety; C: Context - primary health care), being established the following question guideline: what are the patient safety challenges described by health professionals in primary health care?

\section{Inclusion criteria}

The refinement of the articles found was based on the eligibility criteria. The pre-established inclusion criteria were: original articles carried out in the context of $\mathrm{PHC}$, published in Portuguese, Spanish or English, on patient safety, whose research subjects included health professionals and/or managers. No time limit was defined. Duplicate studies, reviews, editorials, theses, dissertations, experience reports, theoretical essays, reflection studies and books were excluded.

\section{Research strategy}

The Virtual Health Library, which included the Latin American and Caribbean Literature in Health Sciences (LILACS), International Health Sciences Literature (MEDLINE), Spanish Health Sciences Bibliographic Index (IBECS), Nursing Database (BDENF) and Cumulative Index to Nursing and Allied Health Literature (CINAHL) was among the checked data sources. Searches for publications indexed in virtual libraries included: Cochrane Library, Scientific Electronic Library Online (SciELO), National Library of Medicine (PubMed and Web of Science). The Google Scholar tool and reference lists from the relevant literature were also checked.

The following controlled terminology descriptors recommended by the Medical Subject Headings (MeSH) and/or the Health Sciences Descriptors (DeCS) were selected: Patient Safety, Safety culture, Safety Management, Primary Health Care, Nursing. All of these terms were searched for in their equivalence in Spanish and Portuguese. The search strategy used followed the definition of each corresponding database. The AND Boolean operator was used with the following combinations: Patient Safety AND Nursing AND Primary Health Care; Safety culture AND Nursing AND Primary Health Care; Safety Management AND Nursing AND Primary Health Care. These search strategies were adopted in their Spanish and Portuguese equivalence and were performed in January 2019. 


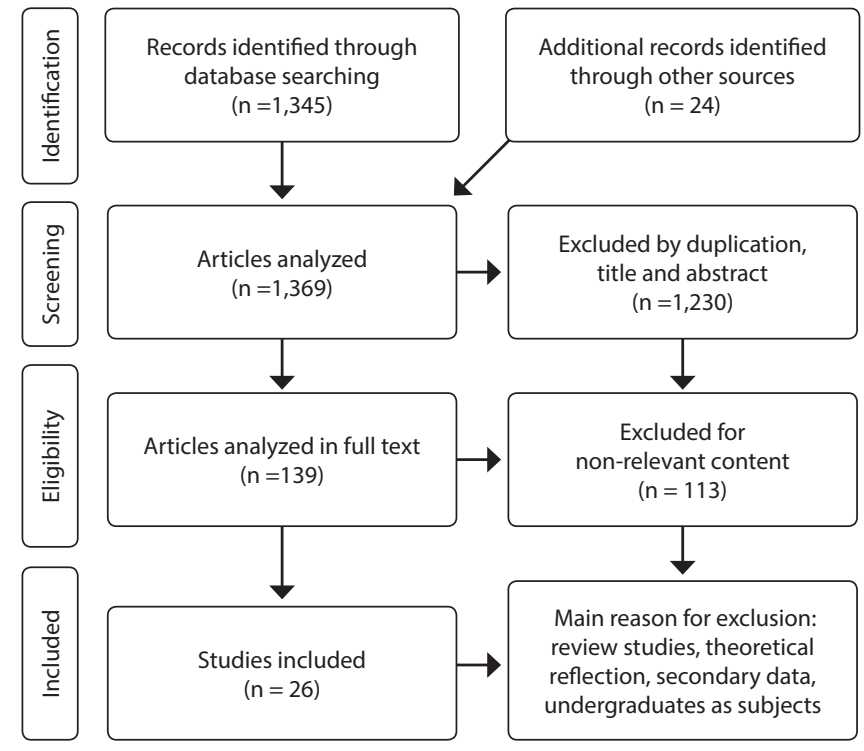

Figure 1 - Flowchart of studies selection that compose the research according to PRISMA SCR ${ }^{(14)}$

For the inclusion process of the studies, the Extension for Scoping Reviews (PRISMA ScR) ${ }^{(14)}$ methodology was chosen. The studies were pre-selected from reading the titles and abstracts, and the final sample was reached based on reading the articles in full, according to the flowchart shown in Figure 1.

\section{Extraction of results}

For the data extraction stage, a structured instrument was used in Microsoft Excel 2011, which provided the identification of the essential elements of the studies, such as author, year of publication, country of study, journal, participants, approach, level of evidence/degree of recommendation ${ }^{(15)}$. This instrument allowed the data to be analyzed using descriptive statistics.

\section{Presentation of results}

For the compilation and communication of the results, a table with the main characteristics of the studies was created, aiming to present an overview of all the material. In addition to a numerical description of the results, a thematic description was organized according to the studies design.

\section{RESULTS}

After the evaluation process and selection of articles, 26 studies were included in the scoping review ${ }^{(1,8,10-11,16-37)}$. They were published between the years 2002 and 2019 (Chart 1). The results will be presented with a description of the characteristics of the studies and, then, the four categories shown from the selected studies are presented: challenges for health professionals; challenges in the management of health services; and challenges with the patient and family. The potential enhancing resources for patient safety conceived to the fourth thematic category.

Chart 1 - Characterization of articles according to author, year of publication, country of study, journal, participants, approach, level of evidence/degree of recommendation, Porto Alegre, Rio Grande do Sul, Brazil, 2019

\begin{tabular}{|c|c|c|c|c|c|}
\hline Author & $\begin{array}{l}\text { Year/ } \\
\text { county }\end{array}$ & Journal & Participants & Approach & $\begin{array}{c}\text { Level of } \\
\text { evidence/ } \\
\text { degree of } \\
\text { recommendation }\end{array}$ \\
\hline $\begin{array}{l}\text { Makeham ABM, } \\
\text { Dovey SM, } \\
\text { County M, Kidd } \\
\text { RM. }^{(36)}\end{array}$ & $\begin{array}{c}2002 \\
\text { Australia, Canada, } \\
\text { Holland, New } \\
\text { Zealand, United } \\
\text { Kingdom and United } \\
\text { States }\end{array}$ & GP Research & 23 general practitioners & $\begin{array}{l}\text { quantitative } \\
\text { study }\end{array}$ & III \\
\hline Bodur S, Filiz E. ${ }^{(25)}$ & $\begin{array}{l}2009 \\
\text { Turkey }\end{array}$ & $\begin{array}{l}\text { Int J Qual Heal } \\
\text { Care }\end{array}$ & $\begin{array}{l}54 \text { general practitioners, } 48 \text { nurses, } 51 \\
\text { midwives, } 27 \text { health workers }\end{array}$ & $\begin{array}{l}\text { quantitative } \\
\text { cross-sectional } \\
\text { study }\end{array}$ & IV \\
\hline $\begin{array}{l}\text { Manwell LB, et } \\
\mathrm{al}^{(34)}\end{array}$ & $\begin{array}{c}2009 \\
\text { United States }\end{array}$ & Wis Med J & 32 doctors & $\begin{array}{l}\text { qualitative } \\
\text { study }\end{array}$ & VII \\
\hline $\begin{array}{c}\text { Sequeira AM, } \\
\text { Martins L, Pereira } \\
\text { VH }\end{array}$ & $\begin{array}{c}2010 \\
\text { Portugal }\end{array}$ & $\begin{array}{l}\text { Rev Port Clin } \\
\text { Geral }\end{array}$ & $\begin{array}{l}8 \text { doctors specializing in general and family } \\
\text { medicine }\end{array}$ & $\begin{array}{c}\text { prospective, } \\
\text { quantitative } \\
\text { cross-sectional } \\
\text { study }\end{array}$ & IV \\
\hline $\begin{array}{c}\text { Paese F, Sasso } \\
\mathrm{G}^{(37)}\end{array}$ & $\begin{array}{l}2013 \\
\text { Brazil }\end{array}$ & $\begin{array}{l}\text { Texto Context } \\
\text { Enferm }\end{array}$ & $\begin{array}{c}52 \text { community health workers, } 30 \text { nursing } \\
\text { technicians and } 14 \text { nurses }\end{array}$ & $\begin{array}{l}\text { cross-sectional, } \\
\text { quantitative } \\
\text { study }\end{array}$ & IV \\
\hline $\begin{array}{l}\text { Gehring K, et } \\
\text { al. }^{(26)}\end{array}$ & $\begin{array}{c}2013 \\
\text { Switzerland }\end{array}$ & $\begin{array}{l}\text { Int J Qual Heal } \\
\text { Care }\end{array}$ & $\begin{array}{c}630 \text { health professionals ( } 314 \text { nurses and } 316 \\
\text { doctors) }\end{array}$ & $\begin{array}{l}\text { cross-sectional, } \\
\text { quantitative } \\
\text { study }\end{array}$ & IV \\
\hline $\begin{array}{l}\text { Torijano- } \\
\text { Casalengua ML, } \\
\text { et al. } .^{(31)}\end{array}$ & $\begin{array}{l}2013 \\
\text { Spain }\end{array}$ & Aten Primaria & $\begin{array}{c}185 \text { health professionals (doctors, nurses and } \\
\text { management staff) }\end{array}$ & $\begin{array}{l}\text { qualitative } \\
\text { study }\end{array}$ & VII \\
\hline
\end{tabular}


Chart 1

\begin{tabular}{|c|c|c|c|c|c|}
\hline Author & $\begin{array}{l}\text { Year/ } \\
\text { county }\end{array}$ & Journal & Participants & Approach & $\begin{array}{l}\text { Level of } \\
\text { evidence/ } \\
\text { degree of } \\
\text { recommendation }\end{array}$ \\
\hline $\begin{array}{l}\text { Verbakel NJ, et } \\
\qquad \text { al. }^{(10)}\end{array}$ & $\begin{array}{l}2014 \\
\text { Holland }\end{array}$ & $\begin{array}{l}\text { Int J Qual Heal } \\
\text { Care }\end{array}$ & $\begin{array}{l}625 \text { workers ( } 150 \text { physical therapists, } 125 \\
\text { midwives, } 99 \text { from anticoagulation clinics, } 70 \\
\text { from speech therapy, } 61 \text { from dental care, } 36 \\
\text { physiotherapist, } 39 \text { occupational therapists, } 26 \\
\text { from skin therapy, } 19 \text { from dietetics }\end{array}$ & $\begin{array}{c}\text { quantitative } \\
\text { cross-sectional } \\
\text { study }\end{array}$ & IV \\
\hline $\begin{array}{l}\text { Bondevik GT, et } \\
\text { al. }^{(22)}\end{array}$ & $\begin{array}{c}2014 \\
\text { Norway }\end{array}$ & $\begin{array}{l}\text { Scand J Prim } \\
\text { Health Care }\end{array}$ & $\begin{array}{c}266 \text { health professionals (139 nurses and } 124 \\
\text { doctors) }\end{array}$ & $\begin{array}{c}\text { quantitative } \\
\text { cross-sectional } \\
\text { study }\end{array}$ & IV \\
\hline $\begin{array}{l}\text { Bondevik GT, et } \\
\text { al. }^{(23)}\end{array}$ & $\begin{array}{c}2014 \\
\text { Norway }\end{array}$ & $\begin{array}{l}\text { BMC Health } \\
\text { Serv Res }\end{array}$ & $\begin{array}{l}266 \text { health professionals (139 nurses and } 124 \\
\text { doctors) }\end{array}$ & $\begin{array}{c}\text { quantitative } \\
\text { cross-sectional } \\
\text { study }\end{array}$ & IV \\
\hline $\begin{array}{l}\text { Bell GB, } \\
\text { et al. }{ }^{(21)}\end{array}$ & $\begin{array}{l}2014 \\
\text { England }\end{array}$ & $\begin{array}{l}\text { BMC Family } \\
\text { Practice }\end{array}$ & $\begin{array}{c}9 \text { experienced specialists in patient safety and } \\
\text { general practice }\end{array}$ & $\begin{array}{l}\text { qualitative } \\
\text { study }\end{array}$ & VII \\
\hline $\begin{array}{c}\text { Webair } \mathrm{HH} \text {, } \\
\text { et al. }{ }^{(17)}\end{array}$ & $\begin{array}{l}2015 \\
\text { Yemen }\end{array}$ & $\begin{array}{l}\text { BMC Family } \\
\text { Practice }\end{array}$ & $\begin{array}{c}78 \text { respondents ( } 17 \text { doctors, } 46 \text { nurses and } 15 \\
\text { management staff) }\end{array}$ & $\begin{array}{l}\text { quantitative } \\
\text { study }\end{array}$ & IV \\
\hline $\begin{array}{l}\text { Marchon SG, } \\
\text { Mendes Junior } \\
\text { WV, Pavão ALB }\end{array}$ & $\begin{array}{l}2015 \\
\text { Brazil }\end{array}$ & $\begin{array}{l}\text { Cad Saúde } \\
\text { Pública }\end{array}$ & 15 health professionals ( 8 nurses and 7 doctors) & $\begin{array}{c}\text { descriptive, } \\
\text { quantitative } \\
\text { observational } \\
\text { study }\end{array}$ & IV \\
\hline Bowie $\mathrm{P}$, et al. ${ }^{(18)}$ & $\begin{array}{l}2015 \\
\text { United Kingdom and } \\
\text { Ireland }\end{array}$ & $\begin{array}{l}\text { Eur J Gen } \\
\text { Pract. }\end{array}$ & $\begin{array}{l}10 \text { professionals (doctors, nurses, practice } \\
\text { managers, patient safety researchers, clinical } \\
\text { educators and medical damages specialists) }\end{array}$ & $\begin{array}{l}\text { qualitative and } \\
\text { quantitative } \\
\text { study }\end{array}$ & $\mathrm{VI}$ \\
\hline $\begin{array}{l}\text { Verbakel NJ, } \\
\text { et al. }^{(20)}\end{array}$ & $\begin{array}{l}2015 \\
\text { Holland }\end{array}$ & Br J Gen Pract & 24 doctors and 24 nurses & $\begin{array}{l}\text { qualitative } \\
\text { study }\end{array}$ & $\mathrm{VI}$ \\
\hline Parker D, et al. ${ }^{(19)}$ & $\begin{array}{l}\qquad 2015 \\
\text { Poland, Germany, } \\
\text { England and Greece }\end{array}$ & Br J Gen Pract. & Primary health care doctors & $\begin{array}{l}\text { qualitative } \\
\text { study }\end{array}$ & $\mathrm{VI}$ \\
\hline $\begin{array}{l}\text { Marchon SG, } \\
\text { Mendes Junior } \\
\text { WV }^{(16)}\end{array}$ & $\begin{array}{l}2015 \\
\text { Brazil }\end{array}$ & $\begin{array}{l}\text { Cad Saúde } \\
\text { Pública }\end{array}$ & $\begin{array}{c}\text { Panel of experts (doctors, researchers, } \\
\text { managers) }\end{array}$ & $\begin{array}{l}\text { qualitative } \\
\text { study }\end{array}$ & VII \\
\hline $\begin{array}{l}\text { Timm M, } \\
\text { Rodrigues } \\
\text { MCS }^{(28)}\end{array}$ & $\begin{array}{l}2016 \\
\text { Brazil }\end{array}$ & $\begin{array}{l}\text { Acta Paul } \\
\text { Enferm }\end{array}$ & $\begin{array}{l}37 \text { professionals } \\
\text { (11 nursing technicians, } 7 \text { nurses, } 4 \text { doctors, } \\
3 \text { dentists, } 3 \text { management staff, } 2 \text { laboratory } \\
\text { technicians, } 1 \text { nutritionist, } 1 \text { oral health } \\
\text { technician, } 1 \text { supervisor, } 1 \text { manager, } 1 \text { head of } \\
\text { nursing, } 1 \text { head of archives department and } 1 \\
\text { community health agent) }\end{array}$ & $\begin{array}{l}\text { methodological } \\
\text { quantitative } \\
\text { study }\end{array}$ & $\mathrm{VI}$ \\
\hline $\begin{array}{l}\text { Paranaguá TTB, } \\
\text { et al. }^{(30)}\end{array}$ & $\begin{array}{l}2016 \\
\text { Brazil }\end{array}$ & $\begin{array}{l}\text { Rev Latino- } \\
\text { Americana } \\
\text { Enferm. }\end{array}$ & $\begin{array}{l}86 \text { health professionals (38 nurses, } 15 \text { dentists, } \\
\qquad 14 \text { doctors) }\end{array}$ & $\begin{array}{l}\text { quantitative } \\
\text { cross-sectional } \\
\text { study }\end{array}$ & IV \\
\hline $\begin{array}{l}\text { López-Liria } \mathrm{R} \text {, et } \\
\qquad \mathrm{al}^{(32)}\end{array}$ & $\begin{array}{l}2017 \\
\text { Spain }\end{array}$ & $\begin{array}{l}\text { Procedia -Soc } \\
\text { Behav Sci. }\end{array}$ & $\begin{array}{l}216 \text { workers ( } 84 \text { nurses; } 80 \text { doctors; } 33 \\
\text { management staff; } 11 \text { nursing assistants; } 6 \\
\text { from ambulances and } 2 \text { physiotherapists) }\end{array}$ & $\begin{array}{l}\text { quantitative } \\
\text { cross-sectional } \\
\text { study }\end{array}$ & IV \\
\hline $\begin{array}{l}\text { Michel P, } \\
\text { et al. }{ }^{(35)}\end{array}$ & 2017 & PLoS One & 127 general practitioners & $\begin{array}{l}\text { quantitative } \\
\text { study }\end{array}$ & IV \\
\hline $\begin{array}{l}\text { Galhardi NM, et } \\
\text { al. }^{(27)}\end{array}$ & $\begin{array}{l}2018 \\
\text { Brazil }\end{array}$ & $\begin{array}{l}\text { Acta Paul } \\
\text { Enferm }\end{array}$ & $\begin{array}{c}240 \text { professionals ( } 18 \text { doctors, } 14 \text { nurses, } 6 \\
\text { dentists, } 2 \text { social workers, } 2 \text { psychologists, } \\
4 \text { pharmacists, } 1 \text { physiotherapist, } 1 \text { speech } \\
\text { therapist, } 15 \text { managers, } 20 \text { management } \\
\text { staff, } 83 \text { community health agents, } 9 \text { nursing } \\
\text { assistants, } 6 \text { pharmacy assistants and } 1 \text { oral } \\
\text { health assistant) }\end{array}$ & $\begin{array}{l}\text { cross-sectional, } \\
\text { quantitative } \\
\text { study }\end{array}$ & IV \\
\hline
\end{tabular}


Chart 1 (concluded)

\begin{tabular}{|c|c|c|c|c|c|}
\hline Author & $\begin{array}{l}\text { Year/ } \\
\text { county }\end{array}$ & Journal & Participants & Approach & $\begin{array}{l}\text { Level of } \\
\text { evidence/ } \\
\text { degree of } \\
\text { recommendation }\end{array}$ \\
\hline $\begin{array}{l}\text { Litchfield l, et } \\
\quad \text { al. }^{(24)}\end{array}$ & $\begin{array}{l}2018 \\
\text { England }\end{array}$ & $\begin{array}{l}\text { BMC Family } \\
\text { Practice }\end{array}$ & $\begin{array}{l}39 \text { interviews (general practitioners, practice } \\
\text { managers, nurses and a health care assistant). }\end{array}$ & $\begin{array}{l}\text { qualitative } \\
\text { study }\end{array}$ & VI \\
\hline Lyson $\mathrm{HC}$, et al. ${ }^{(33)}$ & $\begin{array}{l}2018 \\
\text { United States }\end{array}$ & Healthcare & $\begin{array}{c}\text { doctors, nurses, team coordinators, } \\
\text { administrative support, pharmacists and } \\
\text { behavioral health specialists }\end{array}$ & $\begin{array}{l}\text { qualitative } \\
\text { study }\end{array}$ & VI \\
\hline $\begin{array}{l}\text { Raimondi DC, } \\
\text { et al. }{ }^{(1)}\end{array}$ & $\begin{array}{l}2019 \\
\text { Brazil }\end{array}$ & $\begin{array}{l}\text { Rev Gaúcha } \\
\text { Enferm }\end{array}$ & $\begin{array}{c}144 \text { workers (63 community health workers, } \\
31 \text { nursing assistants and/or technicians, } 16 \\
\text { nurses, } 15 \text { dentists, } 11 \text { oral health technicians } \\
\text { and } 8 \text { doctors) }\end{array}$ & $\begin{array}{l}\text { cross-sectional, } \\
\text { quantitative } \\
\text { study }\end{array}$ & IV \\
\hline $\begin{array}{l}\text { Silva APF, } \\
\text { et al. }{ }^{(11)}\end{array}$ & 2019 & $\begin{array}{l}\text { Rev Gaúcha } \\
\text { Enferm }\end{array}$ & 10 nurses & $\begin{array}{l}\text { qualitative } \\
\text { study }\end{array}$ & VI \\
\hline
\end{tabular}

\section{Description of the studies}

The largest number of publications $(n=6)$ was in 2015(8,16-20), followed by $(n=4)$ in $2014^{(10,21-23)}$. As for editorial aspect, the studies were published in 18 scientific journals, three in Family Practice ${ }^{(17,21,24)}$ and in the International Journal for Quality in Health Care $^{(10,25-26)}$, and two in Acta Paulista Enfermagem ${ }^{(27-28)}$, Revista Gaúcha de Enfermagem ${ }^{(1,11)}$, Cadernos de Saúde Pública ${ }^{(8,16)}$ and European Journal of General Practice ${ }^{(18-19)}$.

As for the country where the studies were developed, most of them $(n=8)$ was in $\operatorname{Brazi}^{(1,8,11,16,27-28,30,37)}$, followed by $(n=2)$ studies in the following countries: Spain ${ }^{(31-32)}$, Holland ${ }^{(10,20)}$, Norway ${ }^{(22-23)}$ and the United States ${ }^{(33-34)}$. Other countries, such as France ${ }^{(35)}$, England $^{(24)}$, Portugal ${ }^{(29)}$, Switzerland ${ }^{(26)}$, Turkey ${ }^{(25)}$ and Yemen ${ }^{(17)}$, presented only one study.

As an inclusion criterion, all studies were carried out with PHC professionals. Of the 26 studies included, 21 involved doctors, 18 included nurses, five included community health workers, four included dentists and three studies, physiotherapists in their sample.

With regard to the methodological approach, 16 publications used the quantitative and nine the qualitative approach, while one study used both ${ }^{(18)}$. As for the data collection instrument, the questionnaire was the most prevalent $(n=20)$, followed by an interview ( $n=3)$, focus group $(n=2)$ and observations $(n=1)$. The most frequent level of evidence $(n=14)$ in the sample was level IV, which corresponds to case report research (including well-designed case-control or cohort) ${ }^{(15)}$.

Among the most used questionnaires in the studies, the following stand out: the Medical Office Survey on Patient Safety Culture

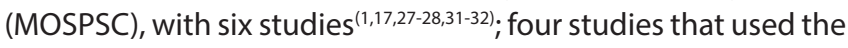
Primary Care International Study of Medical Errors (PCISME) ${ }^{(8,16,29,36)}$; three that used the Safety Attitudes Questionnaire ${ }^{(22-23,37)}$; and a study that used the modified version of the Hospital Survey on Patient Safety Culture (HSOPSC) ${ }^{(25)}$.

\section{Challenges for health professionals}

There is a multiplicity of approaches in the literature related to the challenges experienced by professionals in PHC services, presenting elements such as: communication about error, errors in knowledge, skills and abilities of professionals, diagnostic error and treatment error. Themes such as the communication about errors, prevention of damage and risks to patients and the mental health of professionals were also identified in this category.

Reports on errors related to the team's work process are frequent in the literature, communication being a recurrent theme in publications ${ }^{(10,33,36-37)}$. The communication between the team leads to effective and efficient collective decision-making about the user's therapeutic plans ${ }^{(34)}$. On the other hand, a study ${ }^{(34)}$ clarifies that poor communication is prevalent in $\mathrm{PHC}$, and the team is unable to participate in shared decision-making. In this sense, the findings point to the existence of miscommunication among professionals, as, sometimes, communication is not well performed nor free from misinterpretations $s^{(8,21,28-29,32,35-37)}$. Authors ${ }^{(21)}$ describe that the health team in $\mathrm{PHC}$ needs to develop skills, training, communication, qualification and responsibility, in addition to knowing the population's health needs.

Other studies ${ }^{(8,19,29,35-36)}$ mention that there are errors in knowledge, skills and abilities by professionals. An example of these errors is the occurrence of some failure in care, either due to mistakes in the execution of a clinical task, or due to failures to recognize the urgency of the disease or its complications ${ }^{(8)}$. Likewise, a wrong treatment decision may also be made for a patient who had the correct diagnosis ${ }^{(36)}$. The lack of professional commitment to the user was also reported in one study ${ }^{(8)}$.

Other studies report diagnostic errors with themes such as: delay in diagnosis and therapy and delay in the interpretation of laboratory findings ${ }^{(8,29,35)}$. A study ${ }^{(21)}$ points that diagnosis, prescription, treatment, monitoring, and referrals are part of the safety process in clinical care.

Studies ${ }^{(8,29,35-36)}$ report the occurrence of errors related to treatment, such as: medication errors; entering poor data in the user registration system; exchange of users' identification; exchanging the name of medicines; and incorrect interpretation of prescriptions by the pharmacy ${ }^{(29)}$. In this sense, a study ${ }^{(34)}$ specifies that the existence of doctors and pharmacists in the workplace helps to avoid inaccuracies with medication.

The communication openness about the error by the professionals was also evidenced in the studies, although to a lesser extent $^{(27,32)}$. One study ${ }^{(10)}$ indicates that the dimension of "intention 
to report incidents" was the lowest. Authors ${ }^{(27)}$ describe that $49 \%$ of participants reported that the service team believes that errors can be used against them. The frequency of reporting incidents was considered low in a study carried out in Turkey ${ }^{(25)}$.

Safe care in the studies analyzed was related to care that avoids harm and risks to the patient ${ }^{(9)}$. A study ${ }^{(9)}$ verified the professionals' concern with technical procedures (hand washing, non-contamination and the use of personal protective equipment), with professional ethics (empathy and bonding) and with welcoming (listening and assisting to everyone the best way possible). Another study ${ }^{(19)}$ specifies that among the indicators of patient safety culture were hand hygiene guidelines, compliance with the regulations on sterilization equipment and the correct maintenance of health equipment.

The findings also indicate a concern with the mental health of primary care professionals ${ }^{(22-23,34)}$. They are reports on the difficulty of the professional in balancing work in PHC and family life, which can affect their attitude and concentration ${ }^{(34)}$. Those with scarcer resources and with a greater number of users, on the other hand, expressed frustration and fatigue ${ }^{(34)}$. Another contributing factor for the occurrence of incidents described in the literature is the pressure for the health team to be more productive in less time ${ }^{(8)}$, in addition to work overload ${ }^{(8)}$.

One study ${ }^{(1)}$ mentions that the culture of patient safety is positive among PHC professionals. On the other hand, authors ${ }^{(8)}$ report that there is little dissemination of the patient safety concept among professionals in Brazil. Thus, the safety culture seems to be difficult for professionals to understand ${ }^{(19)}$, being considered poor even in a study carried out in Spain ${ }^{(31)}$.

\section{Challenges in the management of health services}

This category shows patient safety challenges related to the management of health services. The findings refer to the working conditions of professionals, the exchange of information with other institutions, procedural errors, misalignment between professional's and manager's values to the policies that change frequently and payment errors.

Studies report that errors in human resource management contribute to $\mathrm{PHC}$ incidents ${ }^{(8,36)}$. A frequent theme in the findings is the excessive work of PHC professionals $s^{(8,11,24,30,37)}$, in addition to the shortage of employees ${ }^{(11,17,24)}$. Thus, authors ${ }^{(29)}$ perceive the need to include more human resources to maintain a safe physical environment. On the other hand, authors ${ }^{(33)}$ describe that the recruitment and full-time maintenance of qualified and motivated personnel are some of the challenges of $\mathrm{PHC}$, because there is still a high turnover of professionals who do not adapt to the work process shared among the team PHC health system.

The architectural difficulties related to the precarious physical structure and the lack of inputs in the unit were evidenced in the finding $s^{(8,11)}$. Some examples of these difficulties are: lack of access ramp, poorly constructed ramps for handicapped people and people with mobility difficulties, uneven floors, unfinished walls and a lack of maintenance of the physical structure ${ }^{(11)}$. Likewise, a study ${ }^{(8)}$ points that the physical design of the health unit is often inadequate. Thus, accessibility, with a focus on physical access, the screening of users in services and access were considered essential components for the safety of health services structure ${ }^{(21)}$.

One study ${ }^{(8)}$ mentions that, among the contributing factors for incidents in the $\mathrm{PHC}$, is the lack of inputs, medicines, reference beds or support to monitor users with mental health demands. Another study ${ }^{(34)}$ clarifies that inadequate resources often push professionals to compromise the quality of care standards. Therefore, having sufficient equipment, supplies, medicines and materials in the health unit promotes safe and higher quality care ${ }^{(21,34)}$.

Failures with dysfunctional referrals ${ }^{(29)}$ or not performing them ${ }^{(29)}$ and communication failures between the RAS services ${ }^{(8)}$ are evidenced as contributing factors for incidents in the PHC. The findings reveal that having reference resources for the user is central in order to offer quality care ${ }^{(34)}$. Therefore, communication with other health institutions was considered fundamental for patient safety in $\mathrm{PHC}^{(10,21,27-28,32)}$.

As for procedural errors ${ }^{(8,29,36)}$, the findings point errors in administrative care, lapses or exchange of user data, failures in medical records and in the reception of patients ${ }^{(9,29)}$. The lack of an electronic system makes it difficult to monitor users ${ }^{(17)}$. Thus, authors $^{(9)}$ refer that not having access to a computer nor to the internet in the PHC service can be a contributing factor to bad incidents.

The findings mention that, among the factors that affect the quality of care, is misalignment between professional's and manager's values ${ }^{(34)}$. A study ${ }^{(37)}$ mentions that the professionals did not express their disagreements with the managers of the health service. In contrast, the manager encourages to use and apply new skills in the service, which favors learning at work ${ }^{(30)}$. Authors ${ }^{(25)}$ specify that developing the patient safety culture should be a priority for PHC managers, since improvement in this aspect is essential ${ }^{(28)}$.

The number of policies and initiatives that change frequently and are introduced by various local, national and international agencies, affects the ability to adopt more innovations for patient safety in the PHC service ${ }^{(24)}$. In this sense, a study ${ }^{(34)}$ reports that health policies impacts the quality of care.

Another challenge related to the management of health services was payment errors ${ }^{(36)}$, with an international study ${ }^{(36)}$ reporting errors in the processing of insurance claims, electronic payments and those charged incorrectly when not receiving care.

\section{Challenges with the patient and family}

In this category, the topic of patient safety stands out directly related to the challenges in the relationship with the user and the family. The following aspects were identified: failures in the communication between professional and user, the user's adherence to treatment, education and user participation and the presence of a collaborator in care.

The findings point to the failures in the communication between the professional and the user ${ }^{(8,29)}$. This may indicate that there is a great cultural gap between the professional and the user, in which, many times, they do not understand what the professional explained, leading to serious risks ${ }^{(29)}$.

Thus, the low adherence to treatment by users occurs due to the professionals' difficulty in establishing personal bonds, in promoting qualified listening and not properly sharing information ${ }^{(8)}$. One 
study points that the highest number of incidents was detected in older patients (over 40 years old) and with chronic diseases ${ }^{(8)}$.

The results also mention that the need to promote user education and participation in their care, in addition to health literacy ${ }^{(21)}$, affects the understanding the information about care and disease prevention. In this sense, a study ${ }^{(33)}$ shows that the user-centered health care model is the most suitable to promote safe care, in which the service needs to be in accordance with the real health needs of the population ${ }^{(33)}$.

Authors ${ }^{(11)}$ report that it is essential to take into account the conditions of users to adhere to the guidelines from educational activities in health, in addition to understanding what they have to follow in the planning agreed with the professional in relation to their therapeutic plan. Thus, the team needs to promote to the user a collaborating person in their care, that is, someone they can count on for support or someone able to clarify the instructions, in order to avoid possible errors about taking medications or continuing treatment ${ }^{(34)}$. Thus, studies ${ }^{(18,27,32)}$ indicate that, to maintain a high level of safety, it is necessary that the user is monitored and is constantly followed by the professionals.

\section{Potential enhancing resources for patient safety}

This category highlights the resources that allow improving patient safety in $\mathrm{PHC}$, that is, the possible strategies to enhance safe health care. The following aspects stand out in this category: in-service training, user involvement, use of technology, new research, non-punitive culture, audits, protocols, human resources and physical structure. It is believed that these resources are the pillars to face the challenges reported in the previous categories.

The resources to enhance patient safety that stood out in the publications are related to in-service training ${ }^{(8,18,26,30)}$, with emphasis on the continuing education of the professional team ${ }^{(8)}$. Thus, there is a need for more training opportunities to prepare professionals for teamwork ${ }^{(18,26)}$. A study reports that only $14 \%$ of professionals stated that they received training on patient safety at work ${ }^{(30)}$.

The findings indicated the need for regular meetings between health professionals, which can strengthen the safety climate in terms of preventing errors ${ }^{(1)}$. A study ${ }^{(20)}$ points out that carrying a workshop contributed to raise awareness of patient safety and involve professionals in changing their attitude. Another resource identified in the literature was the user's involvement in their care, which was identified as an important solution in $\mathrm{PHC}^{(8)}$.

Another resource described in the studies analyzed is the use of technology as an ally to promote patient safety ${ }^{(8,34-35)}$. Studies ${ }^{(8,35)}$ refer to the need to establish medical records and electronic prescriptions ${ }^{(35)}$, alarms in prescription software, support systems for clinical decisions ${ }^{(8)}$, formal error notification systems ${ }^{(34)}$ and sharing information mechanisms on these $\mathrm{e}^{(34)}$. The findings also highlight the need to develop new systems or increase existing ones, in order to minimize the risk of errors and avoidable damage to users ${ }^{(18)}$.

Conducting new researches was also evidenced in the studies as a resource to improve patient safety. Authors report ${ }^{(8)}$ that new research should enter the health policy agenda, aiming at safer care. Further studies with the application of specific questionnaires, such as the Medical Office Survey on Patient Safety
Culture ${ }^{(17)}$ and the patient satisfaction questionnaire ${ }^{(21)}$, need to be used in PHC, in addition to the development of new instruments aimed specifically at these services ${ }^{(25)}$.

Non-punitive culture was mentioned in only two studies ${ }^{(8,25)}$. One ${ }^{(25)}$ mentions the need to develop a work environment where professionals can report errors or its possibility, without fear of punishment. Authors ${ }^{(21)}$ clarify the need to establish audits to identify incidents and adverse events, with a view to repairing the damage caused, either with responses to errors or with the resolution of complaints ${ }^{(21)}$. The findings indicate some needs: involving professionals in strategies for implementing safe practice protocols ${ }^{(8)}$; the presence of a clinical pharmacist in the $\mathrm{PHC}$ service ${ }^{(8)}$; and financing and support for the construction of clinical environments with open physical space ${ }^{(26)}$.

With regard to the physical structure of the services, a study ${ }^{(33)}$ demonstrated that physical environments adequately designed for the health team, with open and shared spaces, are fundamental for spontaneous, collaborative and shared communication, which favors joint decision making between all professionals. On the other hand, when the physical space is insufficient and poorly designed, it creates an inefficient work environment, which compromises the safety ${ }^{(33)}$. In this sense, the findings also point that patient safety issues need to be addressed more systematically in PHC, in order to identify weaknesses and motivate interventions to reduce the risk of errors by professionals and negative results in users ${ }^{(22)}$.

\section{DISCUSSION}

In this study it was found that the production of knowledge related to patient safety increased significantly in the scientific community in 2015. It can be speculated that this is a repercussion of the report by The Health Foundation, launched in 2013, which emphasized the need to know which methods, tools and indicators are currently being used in primary care to measure patient safety ${ }^{(38)}$.

In this research, quantitative manuscripts were the most recurrent type. A literature review ${ }^{(39)}$ of on this same theme corroborates our findings by also evidencing a greater presence of quantitative studies. It is essential that there is more research using mixed approaches (quantitative and qualitative), in view of the complexity and uniqueness of the human beings involved in health care ${ }^{(39)}$.

Our results reveal that the questionnaire was the most used data collection instrument. One study ${ }^{(2)}$ corroborates these findings, indicating that the questionnaire is the data collection instrument of most studies that assess the safety culture in health services. Thus, in this review, the Medical Office Survey on Patient Safety Culture ${ }^{(31)}$ was the most used instrument. This questionnaire consists of 12 domains (communication openness; communication about error; exchange of information with other hospital units; office processes and standardization; organizational learning; overall perceptions of safety and quality; hospital management support for patient safety; follow-up of patient care; issues related to patient safety and quality; team training; teamwork; and pressure at work and pace) that involve and measure the patient safety culture, of which six are specific to primary care ${ }^{(31)}$. 
As main findings, three main categories of challenges stand out, which are related to health professionals, service management and users and family members. A review study ${ }^{(40)}$ indicates that the teamwork domain, communication and management perception were present in all investigated patient safety instruments.

Our results showed that communication about errors are the main factors associated with incidents. Another study ${ }^{(41)}$ reinforces this result, by demonstrating that the communication failure between the health team or between professionals and users was considered the most relevant contributing factor for incidents ${ }^{(41)}$.

The events that happen in the PHC services need to be seen in their entirety, because, as presented in this review, the management of health services also brings numerous challenges. $A$ study ${ }^{(42)}$ corroborates these results by identifying that among the main causes of adverse events in nursing care are staff shortages, work overload and lack of adequate nursing leadership and supervision, all aspects related to service management.

In this sense, it is known that the users have the potential to play an important role in the prevention of errors, however, little is explored to effectively involve them in this role of vigilance in care $^{(43)}$. Although, in our study, the challenges of the user and the family are the category with the least number of findings, the WHO recommends that professionals and the health system need to openly support and encourage the participation of the users and their families in the construction of a safer health system ${ }^{(44)}$.

In-service training was the resource to enhance patient safety with greater occurrence in the studies analyzed. A research ${ }^{(45)}$ confirms this finding by mentioning that some teaching strategies, such as Permanent Education in Health and the insertion of the theme in the training of professionals, can prevent the occurrence of errors in health care. From this point of view, education for patient safety is a WHO recommendation, which proposed a curriculum protocol with guidelines and recommendations that address issues related to the communication of health professionals, evidence-based practices, teamwork, the bioethics of errors and safe assistance ${ }^{(46)}$.

As in our results, a study ${ }^{(47)}$ carried out with primary care professionals agrees that electronic records allow a more secure service to be provided. One author ${ }^{(48)}$ confirms these results by stating that the implementation of electronic health records qualifies the care provided and helps to achieve patient safety. The electronic medical record can support professionals' decision-making, in addition to reducing expenses and increasing user satisfaction.

Further research in primary care to measure patient safety was identified as necessary by the studies reviewed. The American Medical Association concluded that there are virtually no reliable studies on how to improve safety in primary care ${ }^{(49)}$. In addition, interventions that address the culture of patient safety in these services are limited compared to hospital care ${ }^{(10)}$.

It is also worth noting that, although evidenced in a modest way in our study, non-punitive culture was present. A study(2) mentions the need for a culture of fair security in organizations, in which there is no punishment for errors, but rather a space for their reporting in an environment that encourages professionals to talk about the failures that have occurred, aiming at preventing new events related to the same cause from happening.

In this context, to achieve the objectives proposed by the
World Alliance for Patient Health ${ }^{(50)}$, public health policies in Brazil need to be strengthened in order to improve the knowledge of professionals about safe care, as well as encourage the dissemination of resources that promote patient safety. Therefore, the policies implemented by the Brazilian Ministry of Health have not been sufficient to stimulate a critical look at this security. In this review, no study was found that mentioned the performance of the Patient Safety Centers in Brazilian health services.

\section{Study limitations}

The study sought to evaluate most of the existing literature. However, some limitations in this process can occur, since there are chances that publishing in other languages and in indexing bases not included in this study. Likewise, the authors acknowledge that important published research may have been left out using our search strategy.

\section{Contributions to the Nursing, Health or Public Policy areas}

The implications of this study for practice can be identified in the sense of strengthening awareness of the topic of patient safety in primary care by health professionals, users, managers, policy makers, educators and researchers. The encouragement of safety among these actors will be a conditioning factor in the development of health services and a potential for strategies aimed at improving quality and reducing incidents in PHC. It is believed that this study contributes significantly to giving visibility to the theme and, thus, collaborates in the identification of resources to promote patient safety in the context of $\mathrm{PHC}$, in addition to helping professionals who provide care to users to reflect on their health practices.

\section{FINAL CONSIDERATIONS}

It was possible to conclude that patient safety challenges are mostly related to health professionals, followed by the management of services and the user and his/her family. As resources to enhance patient safety, this study points to the importance of supporting permanent educational processes in services, the use of technologies such as electronic medical records and new research in the area of PHC. Education initiatives need to be able to awaken professionals to change their attitude by reflecting on their work process, with a view to developing safe care. It is believed that these resources are support to face the patient safety challenges evidenced by the subjects of this study.

Therefore, despite the various barriers and challenges that need to be faced to improve patient safety in health services, there remains a need to strengthen and disseminate initiatives that promote safe care. It is recommended that further studies on patient safety in PHC be a priority in the agenda of Brazilian health policy.

\section{FUNDING/ACKNOWLEDGMENT}

To the Coordination for the Improvement of Higher Education Personnel (CAPES) and its National Postdoctoral Program (PNPD) with a scholarship granted to the first author at the Postgraduate Program in Nursing of the Federal University of Rio Grande do Sul. 


\section{REFERENCES}

1. Raimondi DC, Bernal SCZ, Oliveira JLC, Matsuda LM. Cultura de segurança do paciente na atenção primária à saúde: análise por categorias profissionais. Rev Gaúcha Enferm. 2019;40(spe):e20180133. doi: 10.1590/1983-1447.2019.20180133

2. Reis CT, Martins M, Laguardia J. A segurança do paciente como dimensão da qualidade do cuidado de saúde: um olhar sobre a literatura. Cien Saude Colet. 2013;18(7):2029-36. doi: 10.1590/S1413-81232013000700018

3. World Health Organization. Summary of Inaugural Meeting of Safer Primary Care Expert Working Group. Safer Primary Care: a Global Challenge. Geneva, 2012.

4. Vasconcelos PF. Segurança do paciente na atenção primária à saúde: o olhar dos gestores, trabalhadores de saúde e pessoas usuárias. In: Segurança do paciente: reflexões teórico-filosóficas e aplicação prática (Orgs) Pereira FGF, Carvalho REFL, Brasil BMBL. Fortaleza: Centro Universitário Estácio do Ceará, 2019.

5. Panesar SS, Silva D, Carson-Stevens A, Cresswell KM, Salvilla AS, Slight SP, et al. How save is primary care? a systematic review. BMJ Qual Saf. 2016;25(7):544-53. doi: 10.1136/bmjqs-2015-004178

6. Mesquita KO, Silva LCC, Cavalcante RML, Siqueira, Freitas CASL, Lira GV. Patient safety in primary health care: an integrative review. Cogitare Enferm [Internet]. 2016 [cited 2019 Mar 10];21(2):01-8. Available from: https://revistas.ufpr.br/cogitare/article/view/45665.

7. Marchon SG, Mendes Jr WVM, Walter V. Segurança do paciente na atenção primária à saúde: revisão sistemática. Cad Saúde Pública. 2014;30(9):1815-35. doi: 10.1590/0102-311X00114113

8. Marchon SG, Mendes Jr WV, Pavão ALB. Characteristics of adverse events in primary health care in Brazil. Cad Saúde Pública. 2015;31(11):2313-30. doi: 10.1590/0102-311X00194214

9. Silva AEBC, Cassiani SHB, Miasso Al, Opitz SP. Problemas na comunicação: uma possível causa de erros de medicação. Acta Paul Enferm. 2007;20(3):272-276. doi: 10.1590/S0103-21002007000300005

10. Verbakel NJ, Van Melle M, Langelaan M, Verheij TJM, Wagner C, Zwart ADLM. Exploring patient safety culture in primary care. Int J Qual Heal Care [Internet]. 2014 [cited 2019 Out 10];26 (6):585-91. Available from: https://www.ncbi.nlm.nih.gov/pubmed/25085256

11. Silva APF, Backes DS, Magnago TSBDS, Colomé JS. Patient safety in primary care: conceptions of family health strategy nurses. Rev Gaúcha Enferm. 2019;40(esp):e20180164. doi: 10.1590/1983-1447.2019.20180164

12. Joanna Briggs Institute. JBI. Reviewer's manual: 2015 edition/supplement. The University of Adelaide, Austrália: JBI; 2015.

13. Arksey H, O'Malley L. Scoping studies: Towards a methodological framework. Int J Soc Res Methodol. 2005;8(1):19-32. doi: $10.1080 / 1364557032000119616$

14. PRISMA. Extension for Scoping Reviews (PRISMA-ScR): checklist and explanation. Ann Intern Med. [Internet] 2018 [cited 2019 Jan 19$]$ ] 169(7):467-473. Available from: https://www.ncbi.nlm.nih.gov/pubmed/30178033

15. Melnyk BM, Fineout-Overholt E. Making the case for evidence-based practice. In: Melnyk BM, Fineout-Overholt E. Evidence-based practice in nursing \& healthcare. A guide to best practice. Philadelphia: Lippincot Williams \& Wilkins; 2005. p.3-24.

16. Marchon SG, Mendes Jr WV. Tradução e adaptação de um questionário elaborado para avaliar a segurança do paciente na atenção primária em saúde. Cad Saúde Pública. 2015;31(7):1395-402. doi: 10.1590/0102-311X00157214.

17. Webair HH, Al-Assani SS, Al-Haddad RH, Al-Shaeeb WH, Selm MAB, Alyamani AS. Assessment of patient safety culture in primary care setting, Al-Mukala, Yemen. BMC Fam Pract[Internet]. 2015 [cited 2019 Mar 13];16:136. Available from: https://www.ncbi.nlm.nih.gov/pmc/ articles/PMC4604039/

18. Bowie P, Forrest E, Price J, Verstappen W, Cunningham D, Halley L, et al. Good practice statements on safe laboratory testing: A mixed methods study by the LINNEAUS collaboration on patient safety in primary care. Eur J Gen Pract [Internet]. 2015 [cited 2019 Feb 6];21 (sup1):19-25. Available from: https://www.ncbi.nlm.nih.gov/pmc/articles/PMC4828633/

19. Parker D, Wensing M, Esmail A, Valderas JM. Measurement tools and process indicators of patient safety culture in primary care: mixed methods study by the LINNEAUS collaboration on patient safety in primary care. Eur J Gen Pract. [Internet] 2015 [cited 2019 Feb 6]; 21 Suppl:26-30. Available from: https://www.ncbi.nlm.nih.gov/pubmed/26339832

20. Verbakel NJ, Bont AA, Verheij TJM, Wagner C, Zwart DLM. Improving patient safety culture in general practice: an interview study. Br J Gen Pract. [Internet]. 2015[cited 2019 Feb 6];65(641):e822-8. Available from: https://www.ncbi.nlm.nih.gov/pubmed/26622035

21. Bell GB, Spencer R, Avery JA, Campbell MS. Tools for measuring patient safety in primary care settings using the RAND_UCLA appropriateness method. BMC Family Practice [Internet] 2014 [cited 2019 Feb 6];15:110. Available from: https://www.ncbi.nlm.nih.gov/pubmed/24902490

22. Bondevik GT, Hofoss D, Hansen EH, Deilkas ECT. Patient safety culture in Norwegian primary care: A study in out-of-hours casualty clinics and GP practices. Scand J Prim Health Care [Internet] 2014 [cited 2019 Feb 6];32(3):132-8. Available from: https://www.ncbi.nlm.nih.gov/ pubmed/25263763

23. Bondevik GT, Hofoss D, Hansen EH, Deilkas ECT. The safety attitudes questionnaire -Ambulatory version: Psychometric properties of the Norwegian translated version for the primary care setting. BMC Health Serv Res [Internet]. 2014 [cited 2019 Feb 6];14:139. Available from: https://bmchealthservres.biomedcentral.com/articles/10.1186/1472-6963-14-139 
24. Litchfield I, Gill P, Avery T, Campbell S, Perryman K, Marsden K, et al. Influences on the adoption of patient safety innovation in primary care: A qualitative exploration of staff perspectives. BMC Family Practice. [Internet] 2018 [cited 2019 Jun 5];19(1):1-12. Available from: https:// bmcfampract.biomedcentral.com/articles/10.1186/s12875-018-0761-2

25. Bodur S, Filiz E. A survey on patient safety culture in primary healthcare services in Turkey. Int J Qual Heal Care[Internet]. 2009 [cited 2019 Feb 6];21(5):348-55. Available from: https://www.ncbi.nlm.nih.gov/pubmed/19700779

26. Gehring K, Schwappach DLB, Battaglia M, Buff R, Huber F, Sauter P, et al. Safety climate and its association with office type and team involvement in primary care. Int J Qual Heal Care [Internet]. 2013[cited 2019 Feb 6];25(4):394-402 Available from: https://www.ncbi.nlm.nih. gov/pubmed/23667155

27. Galhardi NM, Roseira CE, Orlandi F de S, Figueiredo RM de. Assessment of the patient safety culture in primary health care. Acta Paul Enferm. 2018;31(4):409-16. doi: 10.1590/1982-0194201800057

28. Timm M, Rodrigues MCS. Adaptação transcultural de instrumento de cultura de segurança para a Atenção Primária. Acta Paul Enferm. 2016;26-37. doi: 10.1590/1982-0194201600005

29. Sequeira AM, Martins L, Pereira VH. Natureza e frequência dos erros na actividade de Medicina Geral e Familiar Geral num ACES- Estudo descritivo. Rev Port Clin Geral [Internet]. 2010 [cited 2019 Apr 6];572-88. Available from: http://rpmgf.pt/ojs/index.php/rpmgf/article/ download/10800/10536

30. Paranaguá TTB, Bezerra ALQ, Tobias GC, Ciosak SI. Support for learning in the perspective of patient safety in primary health care. Rev Latino-Americana Enferm. [Internet] 2016 [cited 2019 Feb 6]; Available from: http://dx.doi.org/10.1590/1518-8345.0784.2771

31. Torijano-Casalengua ML, Olivera-Cañadas G, Astier-Peña MP, Maderuelo-Fernández JÁ, Silvestre-Busto C. Validation of a questionnaire to assess patient safety culture in Spanish Primary Health Care professionals. Aten Primaria [Internet]. 2013 [cited 2019 Feb 6];45(1):22-37. Available from: https://www.ncbi.nlm.nih.gov/pubmed/22981282

32. López-Liria R, Rocamora-Pérez P, Aguilar-Parra JM, Vargas-Muñoz ME, del Pilar Díaz-López M, Padilla-Góngora D. Evaluation in Primary Care Professionals: The Patient's Safety Culture. Procedia -Soc Behav Sci[Internet]. 2017[cited 2019 Feb 6]. Available from: https://doi. org/10.1016/j.sbspro.2017.02.209

33. Lyson HC, Ackerman S, Lyles C, Schillinger D, Williams P, Gourley G, et al. Redesigning primary care in the safety net: a qualitative analysis of team-based care implementation. Healthcare[Internet]. 2018[cited 2019 Feb 6];1-8. Available from: https://www.ncbi.nlm.nih.gov/ pubmed/30552044

34. Manwell LB, Williams ES, Babbott S, Rabatin JS, Linzer M. Physician Perspectives on Quality and Error in the Outpatient Setting. Wis Med J[Internet]. 2009 [cited 2019 Feb 6];108(3):139-44. Available from: https://www.ncbi.nlm.nih.gov/pubmed/19552351

35. Michel P, Brami J, Chanelière M, Kret M, Mosnier A, Dupie I, et al. Patient safety incidents are common in primary care: A national prospective active incident reporting survey. PLoS One[Internet]. 2017[cited 2019 Feb 6]. Available from: https://www.ncbi.nlm.nih.gov/ pubmed/28196076

36. Makeham ABM, Dovey MS, County M, Kidd RM. An international taxonomy for errors in general practice: a pilot study. GP Res [Internet]. 2002 [cited 2019 Feb 6];177:68-72. Available from: https://www.ncbi.nlm.nih.gov/pubmed/12098341

37. Paese F, Teresinha Marcon Dal Sasso G. patient safety culture in primary health care. Texto e Contexto Enferm [Internet]. 2013 [cited 2019 Feb 6];22(2):302-12. Available from: http://www.scielo.br/pdf/tce/v22n2/v22n2a05

38. Vincent C, Burnett S, Carthey J. Health Foundation Spotlight report 'The Measurement and Monitoring of Safety.' [Internet]. The Health Foundation. 2013 [cited 2019 Feb 6]. Available from: www.health.org.uk/measuresafety

39. Gomes ATL, Salvador PTCO, Rodrigues CCFM, Silva MF, Ferreira LL, Santos VEP, et al. Patient safety in nursing paths in Brazil. Rev Bras Enferm. 2017;70(1):146-54. doi: 10.1590/0034-7167-2015-0139

40. Vasconcelos PF, Arruda LP, Sousa Freire VEC, Carvalho REFL. Instruments for evaluation of safety culture in primary health care: integrative review of the literature. Public Health [Internet]. 2018 [cited 2019 Feb 6];56:147-51. Available from: https://www.sciencedirect.com/science/ article/pii/S0033350618300039

41. Lang S, Garrido MV, Heintze C. Patients' views of adverse events in primary and ambulatory care: A systematic review to assess methods and the content of what patients consider to be adverse events. BMC Fam Pract. 2016;27;17:6. doi: 10.1186/s12875-016-0408-0

42. Duarte SCM, Stipp MAC, Silva MM, Oliveira FT, Duarte SCM, Stipp MAC, et al. Adverse events and safety in nursing care. Rev Bras Enferm. 2015;68(1):144-54. doi: 10.1590/0034-7167.2015680120p

43. Hibbard JH, Peters E, Slovic P, Tusler M. Can patients be part of the solution? Views on their role in preventing medical errors. Med Care Res Rev [Internet]. 2005 [cited 2019 Feb 6];62(5):601-16. Available from: https://www.ncbi.nlm.nih.gov/pubmed/16177460

44. World Health Organization. Patient safety workshop: learning from error. WHO, editor. Geneva; 2010.

45. Wegner W, Silva SC da, Kantorski KJC, Predebon CM, Sanches MO, Pedro ENR, et al. Education for culture of patient safety: Implications to professional training. Rev Enferm [Internet] 2016 [cited 2019 Mar 6];20(3). Available from: http://www.gnresearch.org/ doi/10.5935/1414-8145.20160068

46. World Health Organization. Patient safety: safer primary care. WHO. Geneva; 2018.

47. McGuire MJ, Noronha G, Samal L, Yeh HC, Crocetti S, Kravet S. Patient Safety Perceptions of Primary Care Providers after Implementation of 
an Electronic Medical Record System. J Gen Intern Med [Internet]. 2013[cited 2019 Feb 6];28(2):184-92. Available from: https://www.ncbi. nlm.nih.gov/pubmed/22887020

48. Cestari VRF. Applicability of assistive innovations and technologies for patient safety: integrative review. Cogitare Enferm [Internet]. 2017 [cited 2019 Feb 18];22(3):e45480. Available from: https://revistas.ufpr.br/cogitare/article/view/45480/pdf

49. Lorincz C, Drazen E, Sokol P, Neerukonda K, Metzger J, Toepp M, et al. Research in Ambulatory Patient Safety 2000-2010: A 10-Year Review[Internet]. Chicago: American Medical Association. 2011 [cited 2019 Feb 6]. Available from: www.ama-assn.org/go/patientsafety

50. World Health Organization. World Alliance for Patient Safety. [Internet]. Geneva: World Health Organization [cited 2019 Feb 29]. Available from: http://www.who.int/patientsafety/worldalliance/en/ 